\title{
Comparative study between microwave and conventional dehydration of okra
}

\author{
By M.H.A. Shams El-Din and A.A. Shouk \\ Food Technology and Dairy Department, National Research Centre, Dokki, Cairo, Egypt.
}

\section{RESUMEN}

Estudio comparativo entre la deshidratación convencional y en microonda del kimbombó.

Este estudio se ha realizado para evaluar los diferentes pretratamientos y métodos de deshidratación en la calidad del kimbombó. No se encontraron diferencias significativas entre ellos respecto a la composición química de las muestras de kimbombó deshidratadas. La inmersión en solución de metabisulfito sódico al $0.1 \%$ a temperatura ambiente y la inmersión en solución de metabisulfito sódico al $0.1 \%$ a $92-95^{\circ} \mathrm{C}$ mejoraron la retención de ácido ascórbico de las muestras de kimbombó después de la deshidratación tanto utilizando el homo convencional como el horno microonda. Además el menor tiempo necesario para la deshidratación usando el horno microondas produjo menos destrucción de ácido ascórbico. La mayor relación de rehidratación fue encontrada en muestras de kimbombó no tratadas o deshidratadas usando horno microondas tras inmersión en metabisulfito sódico al $0.1 \%$ y $92-95^{\circ} \mathrm{C}$. Las muestras de kimbombó deshidratadas por secado al sol y horno convencional tuvieron menores porcentajes de retención de clorofilas totales y carotenoides que las de muestras de kimbombó deshidratadas usando horno microondas. La apariencia general y la calidad del color de las muestras de kimbombó deshidratadas mediante horno microondas fueron significativamente diferentes de aquéllas deshidratadas mediante horno convencional o secadas al sol.

PALABRAS-CLAVE: Carotenoide - Clorofila - Deshidratación Kimbombó - Microondas - Vitamina $C$.

\section{SUMMARY}

Comparative study between microwave and conventional dehydration of okra.

This study was conducted to evaluate different pre-treatments and dehydration methods on the quality of okra. No significant differences were found among pretreatments and dehydration methods for the chemical composition of dehydrated okra samples. Dipping in $0.1 \%$ sodium metabisulphite solution at room temperature and immersion in $0.1 \%$ sodium metabisulphite solution at $92-95^{\circ} \mathrm{C}$ improved the retention of ascorbic acid of okra samples after dehydration by either conventional or microwave oven. Also, the reduced dehydration time required for microwave dehydration produced far less destruction of ascorbic acid. The highest rehydration ratio was found in unwashed okra sample and dehydrated by microwave after immersion in $0.1 \%$ sodium metabisulphite solution at $92-95^{\circ} \mathrm{C}$. Dehydrated okra samples by sun drying and conventional oven had lower retention percentages of total chlorophyll and carotenoids than those of dehydrated okra samples by microwave oven. The general appearance and colour scores of dehydrated okra samples by microwave were significantly different from those of conventionally dehydrated or sun dried okra samples.

KEY-WORDS: Carotenoid - Chlorophyll - Dehydration - Microwaves - Okra - Vitamin C.

\section{INTRODUCTION}

Okra is one of the best vegetables for the tropics. It is easy to cultivate, suited to regions with moderate rainfall and is normally grown during the summer. The most extensive use of okra in home garden, on the small farm and at the large agricultural-enterprise level (Martin and Ruberte, 1978). Okra is also a crop of significant nutritional value and is used in the fresh state or the product may be preserved for later use. Dehydrated foods and the dried components of many formulated or manufactured foods, are now common-place articles of commerce. Drying is becoming a standard processing operation. It's technology is now rather well defined and it is carried out in well tested types and sizes of equipment to produce billions of pounds of dry product annually (Van Arsdel, 1965).

Microwave processes offer a lot of advantages such as less start up time, faster heating, energy efficiency (most of the electromagnetic energy is converted to heat), space savings, precise process control and food product with better nutritional quality. Industrial and home usage is increasing. Primary use in the home is re-heating while tempering, cooking, drying and pasteurization are the main applications in industry (Decareau, 1985).

In the evaluation of a dehydrated food product many factors important to the consumer must be considered, such as appearance, taste, texture, colour, odour, convenience of preparation and nutritional quality of the product. (Krutman, 1981) found that, the best sensory quality and ascorbic acid retention for cabinet and solar dried okra were obtained with blanching in boiling water solution of $0.1 \% \mathrm{SO}_{2}$ for $3 \mathrm{~min}$. Dehydration of okra let to high decrease in the pigments of all treatments (Nezam El-Din and El-Ashwah, 1991).

This study was carried out to evaluate different dehydration methods (microwave, conventional and sun drying) on selected properties of dehydrated okra.

\section{MATERIALS AND METHODS}

\subsection{Materials}

Green fresh okra pods (Hibiscus esculentus) were obtained from the local market, Cairo, Egypt. 


\subsection{Methods}

\section{Preparation of green fresh okra pods for dehydration}

The pods were sized $(3-4 \mathrm{~cm})$, washed, divided into four parts and subjected to the following technological treatments:

A. The first part: Green fresh okra pods were dehydrated without any pretreatment using:

1. A Gold Star microwave oven (Model ER$535 \mathrm{MD}$ ), $2450 \mathrm{MHz}$ on high power level for $18-20 \mathrm{~min}$.

2. An air dry oven at $60^{\circ} \mathrm{C}$ for $12 \mathrm{hr}$.

3. Sun drying for comparison.

B. The second part: Green fresh okra pods were dipped in $0.1 \%$ sodium metabisulphite $\left(\mathrm{Na}_{2} \mathrm{~S}_{2} \mathrm{O}_{5}\right)$ solution for $30 \mathrm{~min}$. at room temperature, then dehydrated with the above mentioned dehydration methods except sun drying.

C. The third part: Green fresh okra pods were immersed in $0.1 \%$ sodium metabisulphite $\left(\mathrm{Na}_{2} \mathrm{~S}_{2} \mathrm{O}_{5}\right)$ solution at $92-95^{\circ} \mathrm{C}$ for $5 \mathrm{~min}$., and divided into two sub-groups, the first was washed using tap water and the other was unwashed, then dehydrated with the above mentioned dehydration methods except sun drying:

D. The fourth part: Green fresh okra pods were blanched in boiling water for $3 \mathrm{~min}$., and divided into two sub-groups, the first was washed using tap water and the other was unwashed, then dehydrated with the above mentioned dehydration methods except sun drying.

\section{Analytical methods}

- Moisture, protein, fat, ash, fibre and ascorbic acid were determined according to the methods recommended by the AOAC (1990). Total carbohydrates were calculated by difference.

- Chlorophyll $a$ and $b$ as well as carotenoids were determined according to Wettestein (1957) using acetone $85 \%$. The pigments content was calculated using the following equations:

Chlorophyll $\mathrm{a}=(9.784 \times \mathrm{E} 662)-(0.99 \times \mathrm{E} \mathrm{664})=\mathrm{mg} . / \mathrm{L}$. Chlorophyll $b=(21.426 \times E$ 644 $)-(4.65 \times E$ 662) $=\mathrm{mg} . / \mathrm{L}$. Carotenoids $=(4.695 \times E$ 440 $)-0.268($ Chl. $a+b)=m g . / L$.

\section{Rehydration measurements}

Ten grams of dried okra pods were placed in boiling water for $10 \mathrm{~min}$., followed by further $10 \mathrm{~min}$. in the same hot water as described by Asghar et al., (1978), then the samples were drained and weighted.

All above-mentioned determinations were performed in duplicate and the mean values were reported.

\section{Sensory evaluation and statistical analysis}

General appearance, colour, odour, taste and texture of dehydrated okra were evaluated organoleptically as described by Nezam EI-Din and El-Ashwah (1991). The mean values for each of the parameters in the organoleptical evaluation was subjected to statistical analysis using analysis of variance and least significant difference (LSD) as reported by Snedecor and Cochran (1980).

\section{RESULTS AND DISCUSSION}

\section{Effect of dehydration methods on the chemical composition of okra pods.}

Data presented in Table I shows the effect of pretreatment and dehydration methods on the chemical composition of dehydrated okra pods. As shown in this table, dehydrated okra samples by microwave oven had the lowest moisture contents compared to other all dehydrated samples. Meanwhile, the highest moisture content was observed in sun-dried okra sample. The all dehydration methods caused a slightly decrease of protein and fat as well as slightly increase of ash, fibre and carbohydrate contents (on dry weight basis), when compared with fresh sample. Similar results were reported by El-Nahry et al., (1978). Okra samples without any pretreatment had more protein, fat and ash, but less fibre and carbohydrates than dipped, blanched and immersed samples after dehydration by conventional and microwave ovens. This might be due to some water-soluble proteins and minerals losses occurred during blanching, dipping and immersion. Meanwhile, the loss of fat during blanching; immersion and dehydration could be due to oxidative reaction or leaching during these treatments of okra. No significant differences were found among pretreatment and dehydration methods for the chemical composition of dehydrated okra samples. 
Table I

Effect of dehydration methods on the chemical composition of okra pods (on dry weight basis)

\begin{tabular}{|c|c|c|c|c|c|c|}
\hline \multirow{2}{*}{ Sample } & \multirow{2}{*}{ Moisture } & \multicolumn{5}{|c|}{ Constituents (\%) } \\
\hline & & Protein & Fat & Ash & Fibre & Carbohydrates \\
\hline Fresh & 87.11 & 18.62 & 2.64 & 7.21 & 15.83 & 55.70 \\
\hline Sun-dried & 9.05 & 18.11 & 2.27 & 7.35 & 16.00 & 56.28 \\
\hline \multicolumn{7}{|l|}{ Dehydrated by conventional oven } \\
\hline Without any pretreatment & 8.20 & 17.84 & 2.34 & 7.32 & 16.05 & 56.45 \\
\hline Blanched in water & 7.95 & 17.35 & 2.26 & 7.28 & 16.20 & 56.91 \\
\hline Dipped in $0.1 \% \mathrm{Na}_{2} \mathrm{~S}_{2} \mathrm{O}_{5}$ solution at room temp. & 8.30 & 17.44 & 2.31 & 7.30 & 16.14 & 56.81 \\
\hline \multicolumn{7}{|l|}{ Immersed in $0.1 \% \mathrm{Na}_{2} \mathrm{~S}_{2} \mathrm{O}_{5}$ solution at $92-95^{\circ} \mathrm{C}$} \\
\hline Washed & 8.10 & 17.24 & 2.25 & 7.26 & 16.15 & 57.10 \\
\hline Un-washed & 7.87 & 17.40 & 2.32 & 7.30 & 16.19 & 56.79 \\
\hline \multicolumn{7}{|l|}{ Dehydrated by microwave oven } \\
\hline Without any pretreatment & 7.11 & 18.06 & 2.46 & 7.28 & 16.15 & 56.05 \\
\hline Blanched in water & 6.96 & 17.65 & 2.37 & 7.23 & 16.29 & 56.46 \\
\hline Dipped in $0.1 \% \mathrm{Na}_{2} \mathrm{~S}_{2} \mathrm{O}_{5}$ solution at room temp. & 7.26 & 17.76 & 2.41 & 7.25 & 16.20 & 56.38 \\
\hline \multicolumn{7}{|l|}{ Immersed in $0.1 \% \mathrm{Na}_{2} \mathrm{~S}_{2} \mathrm{O}_{5}$ solution at $92-95^{\circ} \mathrm{C}$} \\
\hline Washed & 7.01 & 17.56 & 2.35 & 7.21 & 16.23 & 56.65 \\
\hline Un-washed & 6.82 & 17.75 & 2.40 & 7.24 & 16.28 & 56.33 \\
\hline
\end{tabular}

\section{Ascorbic acid retention of dehydrated okra samples}

Ascorbic acid is easily destroyed. It is vulnerable to heat and oxidation; therefore, the method of vegetables dehydration is very important. Ascorbic acid retention of okra samples after conventional and microwave dehydration as well as sun-drying methods were determined. The results are shown hereafter in Table II. Data presented in this table showed that, all dehydration methods of fresh okra pods caused a noticeable decrease in ascorbic acid contents. The highest loss in ascorbic acid was observed in sun dried okra sample being about $74 \%$ followed in a decreasing order by the conventional and microwave dehydrated samples. Rapid drying retains greater amounts of ascorbic than those of slow drying. Generally, the vitamin C content of vegetable tissue is greatly reduced during a slow sun drying process (Salunkhe and Bolin, 1973). Okra samples dehydrated without any pretreatment by either conventional or microwave oven had higher ascorbic acid contents than blanched okra samples in water. Similar results were achieved by Stone et al., (1986). Data in the same table showed also that dipping in $0.1 \%$ sodium metabisulphite solution at room temperature and immersion of okra samples in $0.1 \%$ sodium metabisulphite solution at $92-95{ }^{\circ} \mathrm{C}$ improved the retention of ascorbic acid after dehydration by conventional and microwave ovens, especially unwashed samples, as seen in the same table. Krutman (1981) reported that, okra blanched in sodium sulfite and cabinet-dried had the highest ascorbic acid content when compared with other pretreatments. Effects of blanching and use of sulfur dioxide as pretreatment before dehydration were more evident after storage (Stone et al., 1986). Immersion of okra samples in $0.1 \%$ sodium metabisulphite solution at $92-95^{\circ} \mathrm{C}$ and dehydration by microwave had the highest ascorbic acid contents when compared with other treatments and dehydration methods. In general, the reduced dehydration time required for microwave dehydration produced far less destruction of ascorbic acid. Similar findings were reported by Mabesa and Baldwin (1979), as well as Chung et al., (1981). They found that, microwave cooked peas had greater retention of total ascorbic acid than peas cooked conventionally. Drying temperature and duration had no significant effect $(p>0.05)$ on the ascorbic acid retention of okra (Stone et al., 1986). 
Table II

Effect of dehydration methods on ascorbic acid content of okra (on dry weight basis)

\begin{tabular}{lcc}
\hline \multicolumn{1}{c}{ Sample } & $\begin{array}{c}\text { Acorbic acid } \\
(\mathrm{mg} / 100 \mathrm{~g})\end{array}$ & $\begin{array}{c}\text { Retention } \\
(\%)\end{array}$ \\
\hline Fresh & 207 & - \\
$\quad$ Sun-dried & 54 & 26.09 \\
Dehydrated samples by conventional oven & 58 & 28.02 \\
$\quad$ Without any pretreatment & 55 & 26.57 \\
Blanched in water & 72 & 34.78 \\
Dipped in 0.1\% $\mathrm{Na}_{2} \mathrm{~S}_{2} \mathrm{O}_{5}$ solution at room temp. & & \\
Immersed in $0.1 \% \mathrm{Na}_{2} \mathrm{~S}_{2} \mathrm{O}_{5}$ solution at $92-95{ }^{\circ} \mathrm{C}$ & 80 & 38.65 \\
$\quad$ Washed & 84 & 40.58 \\
$\quad$ Un-washed & & \\
Dehydrated samples by microwave oven & 98 & 47.34 \\
$\quad$ Without any pretreatment & 96 & 46.38 \\
Blanched in water & 102 & 49.28 \\
$\quad$ Dipped in $0.1 \% \mathrm{Na}_{2} \mathrm{~S}_{2} \mathrm{O}_{5}$ solution at room temp. & & \\
Immersed in $0.1 \% \mathrm{Na}_{2} \mathrm{~S}_{2} \mathrm{O}_{5}$ solution at $92-95{ }^{\circ} \mathrm{C}$ & 110 & 53.14 \\
$\quad$ Washed & 115 & 55.56 \\
$\quad$ Un-washed & &
\end{tabular}

\section{Rehydration quality of dried okra}

The rehydration ratios of dried okra samples by different methods are given in Table III. Data in this table showed that, dehydrated okra samples by microwave oven improved the rehydration quality. The lowest rehydration ratio was observed in sun-dried okra sample. Meanwhile, the highest rehydration and dehydrated by microwave ratio was found in unwashed okra sample and dehydrated by microwave after immersion in $0.1 \%$ sodium metabisulphite solution at 92-95 ${ }^{\circ} \mathrm{C}$. Similar results were previously reported by Nezam El-Din and El-Ashwah (1991). From the obtained results in Table III, it was also noticed that no significant differences were found between untreated and blanched okra samples which dehydrated by either conventional or microwave oven.

\section{Table III}

Effect of dehydration methods on rehydration ratio of okra

\begin{tabular}{lc}
\hline \multicolumn{1}{c}{ Sample } & $\begin{array}{c}\text { Rehydration } \\
\text { ratio }\end{array}$ \\
\hline Sun-dried & 3.81 \\
Dehydrated samples by conventional oven & 3.85 \\
Without any pretreatment & 3.87 \\
Blanched in water & 4.12 \\
Dipped in $0.1 \% \mathrm{Na}_{2} \mathrm{~S}_{2} \mathrm{O}_{5}$ solution at room temp. & \\
Immersed in $0.1 \% \mathrm{Na}_{2} \mathrm{~S}_{2} \mathrm{O}_{5}$ solution at $92-95^{\circ} \mathrm{C}$ & 4.00 \\
$\quad$ Washed & 4.32 \\
$\quad$ Un-washed & \\
Dehydrated samples by microwave oven & 5.59 \\
Without any pretreatment & 5.69 \\
Blanched in water & 6.14 \\
Dipped in $0.1 \% \mathrm{Na}_{2} \mathrm{~S}_{2} \mathrm{O}_{5}$ solution at room temp. \\
Immersed in $0.1 \% \mathrm{Na}_{2} \mathrm{~S}_{2} \mathrm{O}_{5}$ solution at $92-95{ }^{\circ} \mathrm{C}$ & \\
$\quad$ Washed & 5.96 \\
\end{tabular}

\section{Pigments content of dried okra}

\section{I.- Chlorophyll $a$ and $b$}

The retention of chlorophyll $\mathrm{a}$ and $\mathrm{b}$ in dried okra samples by the different investigated methods is shown in Table IV. It was revealed that, chlorophyll a and $\mathrm{b}$ contents were found to be decreased after all dehydration methods. These results were in close agreement with those previously reported by Nezam El-Din and El-Ashwah (1991). They reported very low chlorophyll retention in dried okra samples when compared to frozen ones, this could be related to the effect of drying methods on changes and degradation of chlorophyll by the reactivation of chlorophyllase. The heat of drying $\left(60-65^{\circ} \mathrm{C}\right)$ had main role in the activation of chlorophyllase and pectin methylesterase. Preservation of okra by dehydration caused an increase in acidity, let to more degradation of chlorophyll (Sweeney and Martin, 1961). The same authors reported that, the destruction of chlorophyll a was found to be the principal factor responsible for colour loss. The highest loss in total chlorophyll was observed in sun-dried okra sample. Meanwhile, the lowest loss in total chlorophyll was found in dehydrated okra samples by microwave oven. Mabesa and Baldwin (1978) observed that, the retention of chlorophyll components was significantly greater after cooking in a domestic microwave oven. Dehydrated okra samples by conventional oven had lower retention percentages of total chlorophyll than those in dehydrated okra samples by microwave oven, which could be explained by faster microwave dehydration period. The results shown in the same table cleared that, immersion of okra samples in $0.1 \%$ sodium metabisulphite solution without washing before dehydration by either conventional or microwave oven retained higher percentages of chlorophyll than other all dried okra samples due to the preservative action of sulfur dioxide and its effect on chlorophyllase inhibition. Asghar et al., (1978) as well as Nezam El-Din and El-Ashwah (1991) came to the same conclusion.

\section{II.- Carotenoids}

The degeneration of carotenoids, with concomitant loss of colour and vitamin A value, is a common problem in the processing and storage of vegetables and fruits. Carotenoids decreased in all okra samples after dehydration (Table IV). Dehydrated okra samples by microwave oven retained the highest percentages of carotenoids, followed in a decreasing order by conventional oven and sun drying methods. The involved short time for dehydration by microwave reduced the destruction of carotenoids. Immersion of okra samples in $0.1 \%$ 
sodium metabisulphite solution at $92-95{ }^{\circ} \mathrm{C}$ before dehydration by either conventional or microwave oven retained greater amounts of carotenoids than other all dried okra samples, as shown in the same table. These results were in accordance with those of Nezam El-Din and El-Ashwah (1991).

Table IV

Effect of dehydration methods on the total chlorophyll and carotenoids of okra

\begin{tabular}{|c|c|c|c|c|}
\hline Sample & $\begin{array}{l}\text { Total Chlorophyll (a \& b) } \\
\text { (mg/100 g) }\end{array}$ & $\begin{array}{l}\text { Retention } \\
\quad(\%)\end{array}$ & $\begin{array}{l}\text { Total carotenoids } \\
(\mathrm{mg} / 100 \mathrm{~g})\end{array}$ & $\begin{array}{l}\text { Retention } \\
\quad(\%)\end{array}$ \\
\hline Fresh & 59.7 & - & 32.9 & - \\
\hline Sun-dried & 20.5 & 34.34 & 6.1 & 18.54 \\
\hline \multicolumn{5}{|l|}{ Dehydrated by conventional oven } \\
\hline Without any pretreatment & 22.5 & 37.69 & 8.4 & 25.53 \\
\hline Blanched in water & 22.1 & 37.02 & 7.5 & 22.80 \\
\hline Dipped in $0.1 \% \mathrm{Na}_{2} \mathrm{~S}_{2} \mathrm{O}_{5}$ solution at room temp. & 24.2 & 40.54 & 9.0 & 27.36 \\
\hline \multicolumn{5}{|l|}{ Immersed in $0.1 \% \mathrm{Na}_{2} \mathrm{~S}_{2} \mathrm{O}_{5}$ solution at $92-95^{\circ} \mathrm{C}$} \\
\hline Washed & 22.4 & 37.52 & 7.6 & 23.10 \\
\hline Un-washed & 26.5 & 44.39 & 9.7 & 29.48 \\
\hline \multicolumn{5}{|l|}{ Dehydrated by microwave oven } \\
\hline Without any pretreatment & 24.5 & 41.04 & 17.5 & 53.19 \\
\hline Blanched in water & 23.9 & 40.03 & 16.1 & 48.94 \\
\hline Dipped in $0.1 \% \mathrm{Na}_{2} \mathrm{~S}_{2} \mathrm{O}_{5}$ solution at room temp. & 26.8 & 44.89 & 18.5 & 56.23 \\
\hline \multicolumn{5}{|l|}{ Immersed in $0.1 \% \mathrm{Na}_{2} \mathrm{~S}_{2} \mathrm{O}_{5}$ solution at $92-95^{\circ} \mathrm{C}$} \\
\hline Washed & 24.3 & 40.70 & 16.3 & 49.54 \\
\hline Un-washed & 29.4 & 49.25 & 19.5 & 59.27 \\
\hline
\end{tabular}

\section{Effect of dehydration methods on the sensory evaluation of okra}

Sensory evaluation data of dehydrated okra samples was statistically analyzed. Means comparison for the parameters general appearance, colour, odour and taste used to evaluate the okra samples are shown in Table V. The obtained results indicated no significant differences $(p<0.01)$ on odour and taste between the all pretreated samples and dehydrated by the different used dehydration methods. The dehydration of okra by microwave oven improved significantly $(p<0.01)$ the general appearance and colour for the all okra samples, when compared with conventional or sun drying methods.

So, it could be concluded that dehydration of okra by microwave caused less destruction of ascorbic acid and improved the retention of pigments percentages (chlorophyll and carotenoids), rehydration ratios as well as general appearance and colour scores, especially after dipping in $0.1 \%$ sodium metabisulphite solution at room temperature and immersion in $0.1 \%$ sodium metabisulphite solution at $92-95^{\circ} \mathrm{C}$. 
Table V

Statistical analysis of sensory scores (LSD) of dehydrated okra

\begin{tabular}{|c|c|c|c|c|}
\hline Sample & General appearance & Colour & Odour & Taste \\
\hline Sun-dried & $5.8^{\mathrm{c}}$ & $5.6^{c}$ & 5.3 & 5.5 \\
\hline \multicolumn{5}{|l|}{ Dehydrated by conventional oven } \\
\hline Without any pretreatment & $5.6^{\mathrm{c}}$ & $5.6^{\mathrm{c}}$ & 5.4 & 5.6 \\
\hline Blanched in water & $5.9^{c}$ & $5.8^{\mathrm{C}}$ & 5.4 & 5.8 \\
\hline Dipped in $0.1 \% \mathrm{Na}_{2} \mathrm{~S}_{2} \mathrm{O}_{5}$ solution at room temp. & $6.1^{\mathrm{bc}}$ & $5.9^{\mathrm{bc}}$ & 5.7 & 6.0 \\
\hline \multicolumn{5}{|l|}{ Immersed in $0.1 \% \mathrm{Na}_{2} \mathrm{~S}_{2} \mathrm{O}_{5}$ solution at $92-95^{\circ} \mathrm{C}$} \\
\hline Washed & $6.0^{\mathrm{bc}}$ & $5.9^{\mathrm{bc}}$ & 5.6 & 5.9 \\
\hline Un-washed & $6.1^{\mathrm{bc}}$ & $6.1^{\mathrm{bc}}$ & 5.8 & 6.0 \\
\hline \multicolumn{5}{|l|}{ Dehydrated by microwave oven } \\
\hline Without any pretreatment & $7.0^{\mathrm{ab}}$ & $6.9^{\mathrm{ab}}$ & 5.7 & 6.0 \\
\hline Blanched in water & $7.3^{\mathrm{a}}$ & $7.2^{\mathrm{a}}$ & 5.8 & 6.1 \\
\hline Dipped in $0.1 \% \mathrm{Na}_{2} \mathrm{~S}_{2} \mathrm{O}_{5}$ solution at room temp. & $7.5^{\mathrm{a}}$ & $7.2^{\mathrm{a}}$ & 6.0 & 6.4 \\
\hline \multicolumn{5}{|l|}{ Immersed in $0.1 \% \mathrm{Na}_{2} \mathrm{~S}_{2} \mathrm{O}_{5}$ solution at $92-95^{\circ} \mathrm{C}$} \\
\hline Washed & $7.6^{\mathrm{a}}$ & & 6.0 & 6.2 \\
\hline Un-washed & $7.8^{\mathrm{a}}$ & $7.4^{\mathrm{a}}$ & 6.3 & 6.5 \\
\hline $\operatorname{LSD}(p<0.01)$ & 1.0502 & 1.0227 & NS & NS \\
\hline
\end{tabular}

The mean scores in column with the same letter or letters are not significant different at $1 \%$. NS $=$ Not Significant.

\section{REFERENCES}

AOAC (1990).- «Official Methods of Analysis».Association of Official Analytical Chemists, Arlington, Virginia, USA.

Asghar, A.; Sami, M.; Nadeem, M.T. and Sattar, A. (1978)."Effect of some predrying unit operations on the chlorophyll stability and nutritional quality of dehydrated peas".-Lebensm. Wiss. und Technol., 11, 15.

Decareau, R. V. (1985).- «Microwaves in the Food Processing Industry».-Academic Press, New York.

El-Nahry, F. I.; El-Ghorab, M. I. and Younes, R. (1978)."Nutritive value of local varieties of fresh and sundried okra (Hibiscus esculentus) pods and seeds".-Qual. Plant. Plant Foods Hum. Nutri., 28 (3), 227.

- Krutman, A. (1981).- - "Development of alternative dehydration methods for okra".-Dissertation Abstracts International, B 42 (2), 551. Order $n^{\circ} 8116882,77$.

Mabesa, L. B. and Baldwin, R. E. (1978).- «Flavor and color of peas and carrots cooked by microwave".-J. Microwave Power, 13 (4), 321.

Mabesa, L. B. and Baldwin, R. E. (1979).- «Ascorbic acid in peas cooked by microwaves".-J. Food Sci., 44, 932.

Matin, F. W. and Ruberte, R. (1978).— - Vegetables for the hot humid tropics. Part 2. Okra Abelmoschus esculentus".- - Horticulturist and Agricultural Research
Techician, respectively. Mayagues Institute of Tropical Agriculture, Agricultural Research, Science and Education Administration, USDA, Mayaguez, P. R. 00708.

Nezam El-Din, A. M. M. and El-Ashwah, F. A. (1991)."Study on the preservation of okra".-Fourth Arab Conference of Food Science and Technology, 5-9 January, 1991, Cairo, Egypt.

Salunkhe, D. K. and Bolin, H. R. (1973).-«Developments in technology and nutritive value of dehydrated fruits, vegetables and their products".-CRC Critical Reviews in Food Technology, 10, 153.

Snedecor, G. W. and Cochran, W. G. (1980).- - Statistical Methods". $-7^{\text {th }}$ Ed. Oxford and IBIT Publ. Co.

Stone, M. B.; Toure, D.; Greig, J. K. and Naewbanij, J.O. (1986).- - Effect of pretreatments and dehydration temperature on color, nutrient retention and sensory characteristics of okra".-J. Food Sci., 51 (5), 1201.

Sweeney, J. P. and Martin, M. E. (1961).- «Stability of chlorophyll in vegetables as affected by $\mathrm{pH}$ »- - Food Technology, 15, 263.

Van Arsdel, W. B. (1965).-_Food dehydration: Recent advances and unsolved problems".-Food Technol., $52,484$. 